\title{
PENGARUH PELAYANAN ( TANGIBLE, RELIABELITY, RESPONSIVINESS, ASSURANCE, DAN EMPHATY ) TERHADAP KEPUASAN KONSUMEN PT NUTRI INTI PRIMA PERKASA MEDAN.
}

\author{
Khamo Waruwu, SE, MM \\ Fakultas Ekonomi Universitas Tjut Nyak Dhien, Program Studi Manajemen \\ Email: Khamowrw@gmail.com
}

\begin{abstract}
This study aims to determine the effect of services consisting of Tangible, Reliability, Responsiviness, Assurance, and Emphaty on the Consumer Satisfaction of PT Nutri Inti Prima Perkasa Medan. The population and sample of 100 customers were taken by purposive sampling. The research instrument was a questionnaire / questionnaire with a Likert scale model. Requirement test is performed to test normality, heteroscedasticity test. The data analysis technique used is multiple regression techniques at the significance level $\alpha=0.05$. The results showed: there was a significant effect between Service on Consumer Satisfaction with $\mathrm{t}$ arithmetic $=2.498$ and t table 1.984 with a coefficient value of 0.430 . based on the results of SPSS output it is known that the R square value of $32.7 \%$, which means that Services can affect Consumer Satisfaction by $32.7 \%$ and the remaining $67.3 \%$ can be influenced by other variables.
\end{abstract}

\begin{abstract}
Abstrak
Penelitian ini bertujuan untuk mengetahui pengaruh Pelayanan yang terdiri dari Tangible, Reliabelity, Responsiviness, Assurance, dan Emphaty terhadap Kepuasan Konsumen PT Nutri Inti Prima Perkasa Medan. Populasi dan sampel sebanyak 100 orang Pelanggan yang diambil secara purposive sampling. Instrumen penelitian adalah angket/kuisioner dengan model skala likert. Uji persyaratan dilakukan untuk menguji normalitas, uji heteroskedastisitas. Teknik analisis data yang digunakan adalah teknik regresi berganda pada taraf signifikansi $\alpha=$ 0,05. Hasil penelitian menunjukkan: ada pengaruh yang signifikan antara Pelayanan terhadap Kepuasan Konsumen dengan $\mathrm{t}_{\text {hitung }}=2.498$ dan $\mathrm{t}_{\text {tabel }} 1.984$ dengan nilai koefisien sebesar 0.430 . berdasarkan hasil output SPSS diketahui bahwa nilai R square sebesar $32.7 \%$ yang artinya Pelayanan dapat mempengaruhi Kepuasan Konsumen sebesar $32.7 \%$ dan sisanya sebesar $67.3 \%$ dapat dipengaruhi oleh variabel lain.
\end{abstract}

Kata Kunci: Pelayanan, Tangible, Reliabelity, Responsiviness, Assurance, Emphaty, kepuasan konsumen

\section{Pendahuluan}

Sebutan Raja, bukan sekedar gelar para raja yang memiliki kekuasaan dalam menjalankan tugas dan mengendalikan semua para rakyatnya, lepas dari kekuasaan para pelanggan juga sering disebutkan sebagai "raja" sering kali kita lihat dari

beberapa buku terutama yang berhubugan dengan bisnis tak kala para calon pelangganya diperakukan seperti raja, kenapa demikian agar para calon pelanggannya mau menerima tawaran yang akan ditawarkan. 
Dalam mempertahankan Pelayanan menjadi tolak ukur pelanggan agar tidak berpaling yang berakibat pada pengurangan jumlah pelanggan, ketika mereka mendapatkan pelayanan yang buruk dan tidak dihargai maka informasi tentang perusahaan atau usaha yang dikelola dengan sangat mudah tersebar, begitu juga sebaliknya jika kita memberikan pelayanan yang bisa memuaskan para pelanggan maka informasi itu juga sangat cepat tersebar, artinya baik buruknya pelayanan yang kita berikan kepada pelanggan, mereka akan bercerita terhadap rekan atau kerabatnya.

Adapun Pelayanan yang disediakan oleh perusahaan adalah dalam hal ditributor obat-obatan kesehatan hewan, ketersediaan prodak misalnya (vaksin buat hewan, alat alat keperluan kandang, Premix (Vitamin Makan Hewan Ternak). Dalam pengedaan prodak tersebut masih terjadi keterlambatan pelayanan sehingga konsumen diharuskan harus memesan ke perusahaan lain lagi, ketepat waktu dalam proses pengiriman barang kadang mengalami kendala diakibatkan prodak yang disediakan berasal dari luar negeri sehingga memerlukan waktu yang sangat lama untuk sampai ke Indonesia belum lagi birokrasi yang terlalu rumit dibagian imigrasi.
Kepuasan konsumen masih belum maksimal dirasakan kombinasi prodak yang belum seluruhnya tersedia. Setiap kosumen mengharapakan ketika mereka membeli sesuatu dapat merasakan kepuasan yang nyata sehingga mereka akan bertahan menjadi pelanggan setia prodak yang kita jual. Banyak perusahaan yang sama tapi perusahaan ini memiliki ke istimewaan barangnya di import dari Eropa, Perusahaan ini bergerak dibidang distributor penyediaan premix dan vitamin untuk kesehatan hewan yang ada di Sumatera Utara dan Aceh.

Setiap usaha yang mengelola tentang produk dan jasa maka Pelayanan dan kepuasan sangat diharuskan, berdasarkan fenomena-fenomena tersebut diatas, saya sebagai penulis tertarik untuk mengetahui kondisi pelanggan PT Nutri Inti Prima Perkasa mengenai Pelayanan terhadap Kepuasan Konsumennya.

\section{Tinjauan Pustaka}

\subsection{Kepuasan Konsumen}

\subsubsection{Pengertian Kepuasan Konsumen}

Berbagai macam cara para produsen dalam menggapai hati para pembelinya guna mempertahankan kelangsungan hidup usaha yang dikelola. Kepuasan itu sendiri berbagai macam perasaan yang dirasakan oleh para pelanggan namun kita bisa lihat pengertian 
dari pada kepuasan konsumen menurut parah ahli berikut ini. Kepuasan sebuah ungkapan para pelanggan ketika mereka senang atau merasa puas terhadap apa yang mereka dapatkan atu belanjakan, berbicara megenai konsumen sering disebut sebagai raja, seperti sapaan yang sering kita dengar bahwa pembeli (konsumen) adalah Raja. Begitu setiap kali kita dengar selogan ini diseluruh penjuru nusantara.

Dikutip dari buku Manajemen Pemasaran Menurut Philip Kotler dan Kevin Lane Keller (2007:177) mengatakan bahwa Kepuasan Konsumen adalah perasaan senang atau kecewa seseorang yang muncul setelah membandingkan kinerja (hasil) produk yang dipikirkan terhadap kinerja yang diharapkan. Memuaskan kebutuhan konsumen adalah keinginan setiap perusahaan.Selain faktor penting bagi kelangsungan hidup perusahaan, memuaskan kebutuhan konsumen dapat meningkatkan keunggulan dalam persaingan. Konsumen yang puas terhadap produk dan jasa pelayanan cenderung untuk membeli kembali produk dan menggunakan kembali jasa pada saat kebutuhan yang sama muncul kembali dikemudian hari. Kepuasan konsumen adalah tingkat perasaan konsumen setelah membandingkan antara apa yang dia terima dan harapannya (Umar,
2005:65). Seorang pelanggan, jika merasa puas dengan nilai yang diberikan oleh produk atau jasa, sangat besar kemungkinannya menjadi pelanggan dalam waktu yang lama.

beberapa pendapat yang sudah disampaikan diatas, ini berarti kepuasan merupakan faktor kunci bagi konsumen dalam melakukan pembelian ulang produk yang ditawarkan dengan kuantitas yang lebih besar sehingga menambah volume penjualan perusahaan secara langsung.

\subsubsection{Faktor - faktor Kepuasan} Konsumen

Dalam menentukan tingkat kepuasan konsumen, terdapat lima faktor utama yang harus diperhatikan oleh perusahaan yaitu :

\section{a. Kualitas produk}

Konsumen akan merasa puas bila hasil evaluasi mereka menunjukkan bahwa produk yang mereka gunakan berkualitas.

\section{b. Kualitas pelayanan}

Terutama untuk industri jasa. Konsumen akan merasa puas bila mereka mendapatkan pelayanan yang baik atau yang sesuai dengan yang diharapkan.

\section{c. Emosional}

Konsumen akan merasa bangga dan mendapatkan keyakinan bahwa orang lain akan kagum terhadap dia bila menggunakan produk dengan merek tertentu yang 
cenderung mempunyai tingkat kepuasan yang lebih tinggi. Kepuasan yang diperoleh bukan karena kualitas dari produk tetapi nilai sosial yang membuat konsumen menjadi puas terhadap merek tertentu.

\section{d. Harga}

Produk yang mempunyai kualitas yang sama tetapi menetapkan harga yang yang relatif murah akan memberikan nilai yang lebih tinggi kepada konsumennya.

\section{e. Biaya}

Konsumen yang tidak perlu mengeluarkan biaya tambahan atau tidak perlu membuang waktu untuk mendapatkan suatu produk atau jasa cenderung puas terhadap produk atau jasa itu.

\subsubsection{Indikator Kepuasan Konsumen}

Sebagai tolak ukur dalam melihat seberapa pengaruhnya kepuasan konsumen terhadap produk yang dikonsimsi (dipergunakan) maka ada beberapa ahli berikut menyampaikan pendapatnya.

Menurut Kotler yang dikutip dari Buku Total Quality Management ada beberapa metode yang dapat digunakan dalam melakukan pengukuran kepuasan pelanggan, diantaranya (Tjiptono, 2003:104):

\section{a. Sistem keluhan dan saran}

Organisasi yang berpusat pelanggan (Customer Centered) memberikan kesempatan yang luas kepada para pelanggannya untuk menyampaikan saran dan keluhan. Informasi-informasi ini dapat memberikan ide-ide cemerlang bagi perusahaan dan memungkinkannya untuk bereaksi secara tanggap dan cepat untuk mengatasi masalah-masalah yang timbul.

\section{b. Ghost shopping}

Salah satu cara untuk memperoleh gambaran mengenai kepuasan pelanggan adalah dengan mempekerjakan beberapa orang untuk berperan atau bersikap sebagai pembeli potensial, kemudian melaporkan temuan-temuannya mengenai kekuatan dan kelemahan produk perusahaan dan pesaing berdasarkan pengalaman mereka dalam pembelian produk-produk tersebut. Selain itu para ghot shopper juga dapat mengamati cara penanganan setiap keluhan.

\section{c. Lost customer analysis}

Perusahaan seyogyanya menghubungi para pelanggan yang telah berhenti membeli atau yang telah pindah pemasok agar dapat memahami mengapa hal itu terjadi. Bukan hanya exit interview saja yang perlu, tetapi pemantauan customer loss rate juga penting, peningkatan customer loss rate menunjukkan kegagalan perusahaan dalam memuaskan pelanggannya. 


\section{d. Survei kepuasan pelanggan}

Umumnya penelitian mengenai kepuasan pelanggan dilakukan dengan penelitian survai, baik melalui pos, telepon, maupun wawancara langsung. Perusahaan akan memperoleh tanggapan dan umpan balik secara langsung dari pelanggan dan juga memberikan tanda (signal) positif bahwa perusahaan menaruh perhatian terhadap para pelanggannya.

Dari keempat hal tersebut kepuasan konsumen sangat penting dalam meningkatkan volume penjualan perusahaan, sehingga para konsumen tidak berpindah pelanggan jika kepuasan yang kita berikan dapat mereka rasakan baik pada saat ditempat pembelian maupun pada saat produk tersebut di pergunakan.

\subsection{Pelayanan}

\subsubsection{Pengertian Pelayanan}

Berikut beberapa pengertian dan definisi tentang Kualitas Pelayanan. Menurut (Tjiptono, 2001) Kualitas merupakan suatu kondisi dinamis yang berpengaruh dengan produk, jasa, manusia, proses dan lingkungan yang memenuhi atau melebihi harapan. Sehingga definisi kualitas pelayanan dapat diartikan sebagai upaya pemenuhan kebutuhan dan keinginan konsumen serta ketepatan penyampaiannya dalam mengimbangi harapan konsumen
(Tjiptono, 2007). Kualitas pelayanan (service quality) dapat diketahui dengan cara membandingkan persepsi para konsumen atas pelayanan yang nyata-nyata mereka terima/peroleh dengan pelayanan yang sesungguhnya mereka harapkan / inginkan terhadap atribut-atribut pelayanan suatu perusahaan. Jika jasa yang diterima atau dirasakan (perceived service) sesuai dengan yang diharapkan, maka kualitas pelayanan dipersepsikan baik dan memuaskan, jika jasa yang diterima melampaui harapan konsumen, maka kualitas pelayanan dipersepsikan sangat baik dan berkualitas. Sebaliknya jika jasa yang diterima lebih rendah daripada yang diharapkan, maka kualitas pelayanan dipersepsikan buruk.

Dari kutipan pendapat diatas bila kita cermati kalimatnya sangatlah masuk akal jika pelayanan adalah merupakan salah satu faktor utama dalam mempertahankan para konsumen.

\subsubsection{Faktor yang mempengaruhi}

\section{Pelayanan}

Dalam berbagai aspek kehidupan hampir semuanya menghadapi yang namnaya pelayanan, pelayanan ini sebagai pengantar dan penyambung lamanaya bisa berhubungan satu sama yang lainnya tentunya tidak lepas dari bagaimana kita melakukannya. 
Pelayanan umum kepada masyarakat akan dapat berjalan sebagaimana yang diharapkan, apabila faktor-faktor pendukungnya cukup memadai serta dapat difungsikan secara berhasil guna dan berdaya guna. Menurut Moenir (2002:88) terdapat beberapa faktor yang mendukung berjalannya suatu pelayanan dengan baik, yaitu:

(1). Faktor kesadaran para pejabat dan petugas yang berkecimpung dalam pelayanan umum; (2). Faktor aturan yang menjadi landasan kerja pelayanan; (3). Faktor organisasi yang merupakan alat serta sistem yang memungkinkan berjalannya mekanisme kegiatan pelayanan; (4). Faktororganisasi yang merupakan alat sertasystem yang memungkinkan berjalannya mekanisme kegiatan pelayanan; (5). Faktor keterampilan petugas; (6). Faktor sarana dalam pelaksanaan tugas pelayanan.

Didalam keenam faktor tersebut mempunyai peranan yang berbeda tetapi salin mempengaruhi dan secara bersamasama akan mewujudkan pelaksanaan pelayanan secara optimal baik berupa pelayanan verbal, pelayanan tulisan atau pelayanan dalam bentuk gerakan/tindakan dengan atau tanpa tulisan. Terdapat tujuh faktor yang mempengaruhi kinerja organisasi. Ketujuh faktor tersebut meliputi: nilai dan budaya (values and culture); proses kerja dan sistem bisnis (work process and business system); kapasitas individu dan tim (individual and job design); penghargaan dan pengakuan (reward and recognition); serta proses manajemen dan system (management process and system). Dengan faktor faktor tersebut perusahaan atau pemerintahan yang berhubungan dengan pelayanan diupayakan memberikan pendidikan dan pelatihan agar menjadi pelayan yang berkualitas sehingga para konsumen merasa senang dan dihargai serta mereka akan bercerita hal yang baik kepada stakeholder yang berdampak pada penambahan konsumen karena mempengaruhi pikiran dengan rasa penasaran mereka, yang tadinya mereka tidak tau akan menjadi tau dan menjadi pelanggan atau konsumen tetap.

\subsubsection{Indikator Kualitas Pelayanan}

Dalam hal pelayanan yang dilakukan oleh produsen dalam meraih hati para konsumennya maka perlu memperhatikan kualitas pelayanan dalam setiap individu yang berkaitan dengan konsumen secara lansung maupun tidak langsung. Menurut Zeithhaml, Parasuraman \& Berry (dalam Hardiansyah 2011:46) untuk mengetahui kualitas pelayanan yang dirasakan secara nyata oleh konsumen, ada indikator kualitas 
pelayanan yang terletak pada lima dimensi kualitas pelayanan, yaitu:

a. Tangible (berwujud)

b. Reliabelity (kehandalan)

c. Responsiviness (ketanggapan)

d. Assurance (jaminan)

e. Emphaty (Empati).

Masing-masing dimensi memiliki indikator-indikator yang akan dijelaskan sebagai berikut :

1. Tangibles (berwujud): kualitas pelayanan berupa sarana fisik perkantoran, komputerisasi administrasi, ruang tunggu, tempat informasi. Indikatornya adalah :

a. Penampilan petugas/aparatur dalam melayani pelanggan

b. Kenyamanan tempat melakukan pelayanan

c. Kemudahan dalam proses pelayanan

d. Kedisiplinan petugas/aparatur dalam melakukan pelayanan

e. Kemudahan akses pelanggan dalam permohonan pelayanan

f. Penggunaan alat bantu dalam pelayanan

2. Realibility (kehandalan) : kemampuan dan keandalan untuk menyediakan pelayanan yang terpercaya. Indikatornya adalah :

a. Kecermatan petugas dalam melayani b. Memiliki standar pelayanan yang jelas

c. Kemampuan petugas/aparatur dalam menggunakan alat bantu dalam proses pelayanan

d. Keahlian petugas dalam menggunakan alat bantu dalam proses pelayanan

3. Responsivess (ketanggapan) : kesanggupan untuk membantu dan menyediakan pelayanan secara cepat dan tepat, serta tanggap terhadap keinginan konsumen. Indikatornya adalah:

a. Merespon setiap pelanggan/pemohon yang ingin mendapatkan pelayanan

b. Petugas/aparatur melakukan pelayanan dengan cepat

c. Petugas/aparatur melakukan pelayanan dengan tepat

d. Petugas/aparatur melakukan pelayanan dengan cermat

e. Petugas/aparatur melakukan pelayanan dengan waktu yang tepat

f. Semua keluhan pelanggan direspon oleh petugas

4. Assurance (jaminan) : kemampuan dan keramahan serta sopan santun pegawai dalam meyakinkan kepercayaan konsumen. Indikatornya adalah :

a. Petugas memberikan jaminan tepat waktu dalam pelayanan 

b. Petugas memberikan jaminan biaya dalam pelayanan

c. Petugas memberikan jaminan legalitas dalam pelayanan

d. Petugas memberikan jaminan kepastian biaya dalam pelayanan

5. Emphaty (Empati) : sikap tegas tetapi penuh perhatian dari pegawai terhadap konsumen. Indikatornya adalah :

a. Mendahulukan kepentingan pelanggan/pemohon

b. Petugas melayani dengan sikap ramah

c. Petugas melayani dengan sikap sopan santun

d. Petugas melayani dengan tidak diskriminatif (membeda-bedakan)

e. Petugas melayani dan menghargai setiap pelanggan

Dari kelima indikator yang telah dijelaskan diatas bahwa pentingnya kualitas pelayanan yang dilakukan oleh produsen dalam memenuhi kepuasan konsumennya agar mereka kembali untuk datang karena atas pertimbangan pelayanan yang mereka rasakan dan alami secara langsung di tempat produsen berada.Untuk itu produsen diharapkan dapat meberikan arahan dan pelatihan bagi seluruh individuu yang berhubungan langsung dengan konsumen agar berdampak baik dalam mencapai kepuasan.

\subsection{Kerangka Konseptual}

Dalam kerangka Konseptual Kepuasan Konsumen (Y) disebut sebagai variabel terikat yang memiliki ketergantungan terhadap variabel bebas dalam hal ini adalah X ( Pelayanan).

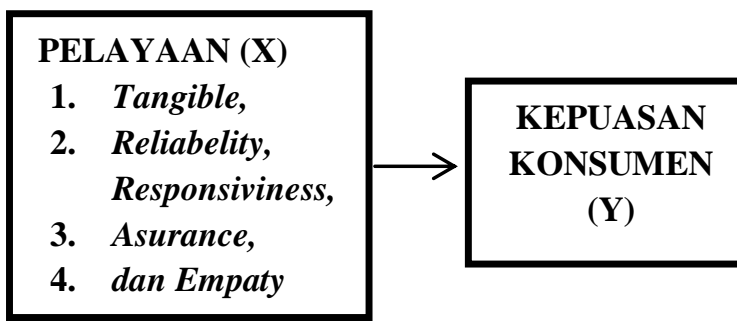

\section{Gambar 2.1. Kerangka Berfikir}

\subsection{Hipotesis}

Hipotesis merupakan anggapan sementara sebelum melakukan penelitian dan hasil yang diharapkan seperti yang diungkapan Sugiono (2004) dalam Albert kurniawan $\quad(2014 ; 25) \quad$ memberikan pengertian bahwa hipotesis adalah merupakan jawaban sementara yang masih harus dibuktikan kebenarannya melalui penelitian. Adapun kriteria hipotesis sebagai berikut:

a) Dinyatakan dalam kalimat yang menyatakan hubungan dalam dua variable atau lebih;

b) Dilandasioleh argumentasi yang kuat berdasarkan teori; 
c) Mendorong untuk dilakukan pengujian (testable);

d) Disusun dalam kalimat yang singkat dan jelas (concise)

e) Konsisten dengan teori yang ada;

f) Memiliki argumentasi yang jalas dan dapat dipertanggungjawabkan secara rasional.

Berdasarkan landasan teoritis dan kerangka berfikir maka hipotesis yang digunakan oleh penulis adalah sebagai berikut:

1. Pelayanan yang terdiri dari Berwujut, Kehandalan, Ketanggapan, Jaminan dan Empati berpengaruh terhadap Kepuasan Konsumen PT Nutri Inti Prima Perkasa Medan.

2. Pelayanan yang terdiri dari Berwujut, Kehandalan, Ketanggapan, Jaminan dan Empati tidak berpengaruh terhadap Kepuasan Konsumen PT Nutri Inti Prima Perkasa Medan.

\section{Metode Penelitian}

Metode yang digunakan dalam penelitian adalah metode kuantitatif, Menurut Sugiyono (14:2015), metode penelitian kuantitatif merupakan metode penelitian yang berlandaskan pada filsafat positivisme, digunakan untuk meneliti pada populasi atau sampel tertentu, teknik pengambilan sampel pada umumnya dilakukan secara random, pengumpulan data menggunakan instrumen penelitian, analisis data bersifat kuantitatif/statistik dengan tujuan untuk menguji hipotesis yang telah ditetapkan.

Populasi dalam penelitian ini adalah karyawan PT Nurti Inti Prima Perkasa Medan yang berjumlah 100 (seratus) orang. Dengan sampel sama dengan populasi yaitu 100 orang. Dalam pengujian data yang telah didapatkan oleh penulis terhadap PT Nutri Inti Prima Perkasa Medan, Penulis menggunakan teknik rumus yang digunakan yaitu regresi sederhana (Simple reression)

Dimana :

$$
\mathrm{Y}=\mathrm{a}+\mathrm{bx}
$$

$\mathrm{Y}=$ Kepuasan Konsumen (Independent Variable)

$\mathrm{a}=$ Intercept yaitu titik potong garis depan dengan sumbu y.

$\mathrm{b}=$ Slope yaitu, kemiringan garis

$\mathrm{x}=$ Pelayanan $($ Dependent Variable $)$

\section{Hasil Penelitian dan Pembahasan}

\subsection{Hasil Penelitian}

4.1.1. Penyajian Data Jawaban Responden

Data yang diperoleh selama penelitian akan disajikan dalam bentuk kuantitatif sebagai hasil penyebaran angket 
Volua Jurnal IImiah Akuntansi Keuangan dan Bisnis

Vol. 1 No. 1 Bulan April - September 2020

kepada 100 orang responden yang juga merupakan sampel jenuh atau jumlah populasi yang ada, dengan jumlah pertanyaan 15 item, yang terdiri dari item pertanyaan Variabel Bebas Variabel Pelayanan dan Variabel Terikat Kepuasan Konsumen.

Tabel 4.1. Karakteristik responden berdasarkan jenis kelamin

\begin{tabular}{|ll|r|r|r|r|}
\hline & & Jenis_kelamin \\
\hline Valid & Laki-laki & 49 & 49.0 & 49.0 & 49.0 \\
& Perempuan & 51 & 51.0 & 51.0 & 100.0 \\
& Total & 100 & 100.0 & 100.0 & \\
\hline
\end{tabular}

Sumber : Hasil Kuesioner 2020

Dari Tabel 4.1. didapat bahwa jumlah responden sebanyak 100 yang dijadikan sebagai sampel yang terdiri dari 51 berjenis kelamin perempuan dan 49 orang berjenis kelamin laki-laki. Selanjutnya tentang keadaan responden berdasarkan usia dapat dilihat pada tabel berikut.

Tabel 4.2. Keadaan responden berdasarkan usia

\begin{tabular}{|c|c|c|c|c|c|}
\hline \multicolumn{6}{|c|}{ Usia } \\
\hline & & Frequency & Percent & Valid Percent & $\begin{array}{l}\text { Cumulative } \\
\text { Percent }\end{array}$ \\
\hline \multirow[t]{6}{*}{ Valid } & $<20$ & 8 & 8.0 & 8.0 & 8.0 \\
\hline & $>55$ & 3 & 3.0 & 3.0 & 11.0 \\
\hline & $21-35$ & 56 & 56.0 & 56.0 & 67.0 \\
\hline & $36-45$ & 31 & 31.0 & 31.0 & 98.0 \\
\hline & $46-55$ & 2 & 2.0 & 2.0 & 100.0 \\
\hline & Total & 100 & 100.0 & 100.0 & \\
\hline
\end{tabular}

Sumber : Hasil Kuesioner 2020

Berdasarkan Tabel 4.2. terdapat jumlah usia paling banyak adalah 21-35 tahun dengan jumlah 56 orang dengan persentase sebesar $(56.0 \%)$.

Dari jawaban responden yang telah diperoleh kemudian diolah dalam bentuk frekuensi yang terdiri dari poin-poin pertanyaan angket penelitian dari variabel bebas dan variabel terikat kemudian ditabulasi untuk mempermudah menganalisis dengan menggunakan model analisis Regresi sederhana dan diolah dengan menggunakan bantuan program Statistical Product and Service Solution (SPSS) vesrsi 20.0. Sebelum menganalisis maka terlebih dahulu dilakukan Uji yaitu Uji Validitas dan Uji Reliabilitas. Data disajikan sebagai berikut:

\subsubsection{Uji Validitas dan Realibilitas}

\section{a. Uji Validitas}

Untuk mengetahui kelayakan dari butir-butir dalam daftar pertanyaan angket yang telah disajikan pada responden maka diperlukan Uji Validitas dengan nilai lebih besar (>0.30), maka butir Totl Statistic, hasil pengolahan SPSS. 20.0 dengan memasukkan data jawaban responden dari X dan Y yang disajikan pada tabel berikut: 


\section{Tabel 4.3. Tabel Hasil Uji Validitas Variabel X}

Item-Total Statistics

\begin{tabular}{|c|r|r|r|r|}
\hline & $\begin{array}{c}\text { Scale Mean if } \\
\text { Item Deleted }\end{array}$ & $\begin{array}{c}\text { Scale } \\
\text { Variance if } \\
\text { Item Deleted }\end{array}$ & $\begin{array}{c}\text { Corrected } \\
\text { Item-Total } \\
\text { Correlation }\end{array}$ & $\begin{array}{c}\text { Cronbach's } \\
\text { Apha if Item } \\
\text { Deleted }\end{array}$ \\
\hline VAR00001 & 14.4100 & 12.022 & .538 & .845 \\
VAR00002 & 14.3500 & 11.987 & .603 & .827 \\
VAR00003 & 14.3900 & 10.240 & .859 & .754 \\
VAR00004 & 14.4600 & 10.574 & .748 & .786 \\
VAR00005 & 14.2700 & 12.684 & .533 & .843 \\
\hline
\end{tabular}

Sumber : Hasil Kuesioner 2020

Nilai corrected item-total correlation dari lima pernyataan di atas > dari 0,1966 yang artinya seluruh butir pernyataan dari variabel bebas yaitu $\mathrm{X}$ diatas dinyatakan valid.

\section{Tabel 4.4. Tabel Hasil Uji Validitas Variabel Y}

\begin{tabular}{|c|r|r|r|r|}
\multicolumn{5}{|c|}{ Item-Total Statistics } \\
\hline & $\begin{array}{c}\text { Scale Mean if } \\
\text { Item Deleted }\end{array}$ & $\begin{array}{c}\text { Scale } \\
\text { Variance if } \\
\text { Item Deleted }\end{array}$ & $\begin{array}{c}\text { Corrected } \\
\text { Item-Total } \\
\text { Correlation }\end{array}$ & $\begin{array}{c}\text { Cronbach's } \\
\text { Alpha if Item } \\
\text { Deleted }\end{array}$ \\
\hline VAR00001 & 11.0200 & 11.212 & .580 & .913 \\
VAR00002 & 11.1300 & 9.165 & .873 & .806 \\
VAR00003 & 11.2200 & 9.507 & .720 & .867 \\
VAR00004 & 11.0600 & 9.027 & .849 & .814 \\
\hline
\end{tabular}

Sumber : Hasil Kuesioner 2020

Nilai corrected item-total correlation dari delapan pernyataan variabel Y di atas > dari 0,1966 yang artinya seluruh butir pernyataan di atas dinyatakan validR tabel untuk responden 200 yaitu 0,1966 Rumus = $\mathrm{df}=\mathrm{n}-2$ maka $\mathrm{df}=100-2=98$ rtabel dengan alpha $5 \%$ adalah $\quad 0,1966 \quad(0,20 \quad$ jika dibulatkan)

\section{b. Uji Reliabilitas (Kehandalan)}

Berdasarkan hasil angket diatas maka untuk mengetahui kestabilan dan konsistensi responden dalam menjawab butir-butir yang berkaitan dengan konstruk pertanyaan yang disusun dalam suatu bentuk kuesioner maka diperlukan $U j i$ Reliabilitasmaka bisa dilihat pada tabel ReliabilityStatistic yang disajikan sebagai berikut :

\section{Tabel 4.5. Tabel Hasil Uji Reliabilitas Variabel X}

\begin{tabular}{|c|r|}
\hline \multicolumn{2}{|c|}{ Reliability Statistics } \\
\begin{tabular}{|c|r|}
\hline $\begin{array}{c}\text { Cronbach's } \\
\text { Alpha }\end{array}$ & N of Items \\
\hline .845 & 5 \\
\hline
\end{tabular}
\end{tabular}

Sumber : Hasil Kuesioner 2020

Suatu variabel dinyatakan reliabel jika nilai cronbach's alpha > 0,60. maka berdasarkan data tersebut seluruh butir pernyataan dinyatakan reliabel karena nilai cronbach's alpha $0,845>$ dari 0,60.

Tabel 4.6. Tabel Hasil Uji

\section{Reliabilitas Variabel Y}

\begin{tabular}{|} 
Reliability Statistics \\
\begin{tabular}{|r|r|}
\hline $\begin{array}{c}\text { Cronbach's } \\
\text { Alpha }\end{array}$ & N of Items \\
\hline .886 & 4 \\
\hline
\end{tabular}
\end{tabular}

Sumber : Hasil Kuesioner 2020

Suatu variabel dinyatakan reliabel jika nilai cronbach's alpha > 0,60. maka berdasarkan data tersebut seluruh butir pernyataan dinyatakan reliabel karena nilai cronbach's alpha 0,886> dari 0,60. 


\section{Uji Asumsi Kelasik}

Dalam penelitian ini uji asumsi klasik yang dilakukan adalah pengujian normalitas, multikolinearitas dan heteroskedastisitas.

\section{a. Uji Normalitas}

Uji normalitas bertujuan untuk menguji apakah dalam model regresi, variabel (Residual) memiliki distribusi normal. Salah satu uji satatistik yang digunakan adalah uji nin parametrik Kolmogoro - Smirnow (K-S) seperti terligat pada gambar berikut :

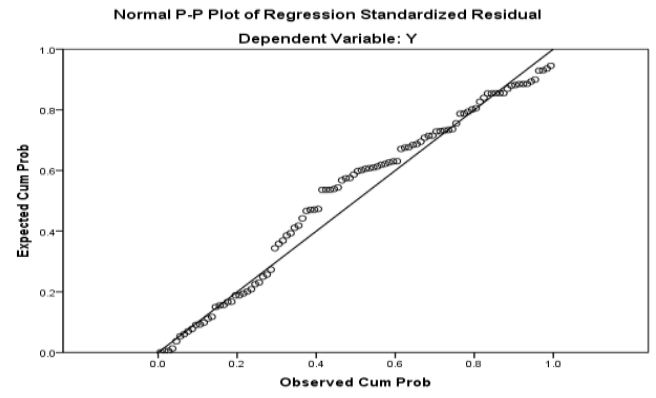

\section{Gambar 4.1. Hasil uji normalitas dalam bnetuk scatterplot}

Sumber : Hasil Kuesioner 2020

Dari gambar scatter plot di atas terlihat titik data Pelayanan dan Kepuasan Konsumenyang mengikuti data disepanjang garis diagonalhal ini berarti data berdistribusi normal. Maka model regresi layak dipakai untuk meprediksi Pelayanan berdasarkan masukan Variabel Indenpenden.

\section{b. Uji Multikolinieritas}

Untuk mengetahui apakah lebih dari satu hubungan linier yang sempurna atau variabel bebas ada korelasi. Untuk mendeteksi ada tidaknya multikolinieritas dapa dilihat dari Value Inflation Factor (VIF).

\section{Tabel 4.7. Hasil Uji Multikolinieritas}

\begin{tabular}{|c|c|c|}
\hline \multicolumn{3}{|c|}{ Coefficientsa } \\
\hline \multirow[t]{2}{*}{ Model } & \multicolumn{2}{|c|}{ Collinearity Statistics } \\
\hline & Tolerance & VIF \\
\hline $1 \quad$ X_KJ & .998 & 1.002 \\
\hline
\end{tabular}

Sumber : Hasil Kuesioner 2020

Jika Nilai VIF $<5$ maka tidak terdapat multikolinieritasjika nilai Tolerance $>0.1$ maka tidak terdapat multikolinieritas. Dari hasil output SPSS di atas terdapat multikolinieritasVIF $=1.002$ yaitu $<5$ Tolerance $>0.1$ yaitu 0.998

\section{c. Uji Heterokedastisitas}

Untuk menunjukan nilai varians antara nilai dependent variabel tidak sama atau varians (Residu) tidak konstan bertujuan untuk menguji apakah dalam sebuah regresi terjadi ketidaksamaan residual dari satu pengamatan.

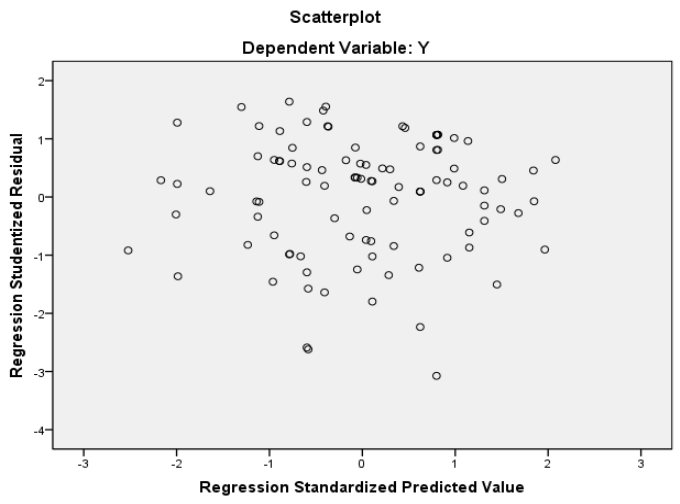

Sumber : Hasil Kuesioner 2020

Gambar 4.2. Hasil Uji Heterokedastisitias 
Dari hasil tampilan utput SPSS diatas dengan jelas menunjukkan penyebaran titik titiksecara acak tidak membentuk pola tertentu yang jelas serta tersebar baik diatas maupun dibawah angka nol pada sumbu Y. Hal ini tidak terjadi heterokedastisitas.

\section{Uji Hipotesis}

\section{Uji Pengaruh Parsial (uji t)}

Uji t dilakukan untuk menguji apakah variabel bebas (X) secara individual mempunyai pengaruh yang signifikan atau tidak terhadap variabel terikat $(\mathrm{Y})$

Tabel 4.8. Hasil Uji t (Coefficients(a)

\begin{tabular}{|c|c|c|c|c|c|}
\hline \multicolumn{6}{|c|}{ Coefficientsa } \\
\hline \multirow[t]{2}{*}{ Model } & \multicolumn{2}{|c|}{$\begin{array}{c}\text { Unstandardized } \\
\text { Coefficients }\end{array}$} & $\begin{array}{l}\text { Standardized } \\
\text { Coefficients }\end{array}$ & \multirow[b]{2}{*}{$\mathrm{t}$} & \multirow[b]{2}{*}{ Sig. } \\
\hline & B & $\begin{array}{l}\text { Std. } \\
\text { Error }\end{array}$ & Beta & & \\
\hline \multirow{3}{*}{$\begin{array}{ll}1 & \text { (Constant) } \\
& \mathrm{X}\end{array}$} & 7,475 & 2,186 & & 3,419 & $\overline{001}$ \\
\hline & ,235 & ,094 & 240 & 2,498 &, 014 \\
\hline & & & & & \\
\hline
\end{tabular}

Sumber : Hasil Kuesioner 2020

Berdasarkan Tabel 4.8 bisa dilihat besaran yang dihasil kan oleh $\mathrm{t}$ hitung dari dua variabel bebas yang akan di bandingkan dengan $\mathrm{t}$ tabel, apakah berpengaruh signifikan atau malah sebaliknya, penjelasannya sebagai berikut :

Pengaruh pelayanan terhadap Kepuasan

Konsumen

Dari tabel diatas menunjukkan ttabelsebesar 2.498 dengan taraf signifikan sebesar 0.014, sedangkan thiung sebesar 1.984, sehingga tabe 2.498> thiung 1.984 maka dapat disimpulkan $\mathrm{H} 0$ ditolak dan Ha diterima.

\section{Uji Koefisien Determinasi}

Koefisien determinasi berfungsi untuk mengetahui persentase besarnya pengaruh variabel independen dan variabel dependen yaitu dengan mengkuadratkan koefisien yang ditemukan. Dlaam penggunaanya, koefisien determinasi ini dinyatakan dalam persentase \%. Untuk megetahui sejauh mana kontribusi atau persentase pengaruh Pelayanan terhadap Kepuasan Konsumen PT Nutri Inti Prima Perkasa Medan

Tabel 4.9. Model Summary (b)

\begin{tabular}{|l|l|r|r|r|}
\hline Model & \multicolumn{1}{c|}{ Model Summary } \\
\hline 1 & \multicolumn{1}{|c|}{$.249^{\mathrm{a}}$} & R Square & $\begin{array}{c}\text { Adjusted R } \\
\text { Square }\end{array}$ & $\begin{array}{c}\text { Std. Error of } \\
\text { the Estimate }\end{array}$ \\
\hline
\end{tabular}
a. Predictors: (Constant), X_KJ
b. Dependent Variable:Y_PK

Sumber : Hasil Kuesioner 2020

$\mathrm{R}$ square digunakan untuk melihat seberapa besar kontribusi (pengaruh) variabel bebas terhadap variabel terikat dengan catatan : Apabila teknik analisis datanya hanya terdiri dari satu sampai dua variabel bebas, maka digunakanl R Square, tetapi apabila jumlah variabel bebasnya lebih dari 2 (dua) maka lebih baik menggunakan Adjusted R Square yang nilainya selalu lebih kecil dari R Square. 
Berdasarkan hasil output SPSS diatas diketahui bahwa nilai $\mathrm{R}$ square sebesar 0,327 atau $32,7 \%$ Pelayanan dapat mempengaruhi Kepuasan Konsumen hingga sebesar $32.7 \%$, dan sisanya sebesar $67,3 \%$ dapat dipengaruhi oleh variabel lain seperti harga, emosi (kepuasan denan menggunkan Brand tertentu), biaya dan kemudahan dan lainnya.

\subsection{Pembahasan}

Berdasarkan hasil pengujian secara statistik dapat terlihat dengan jelas bahwa secara parsial (individu) semua variabel bebas berpengaruh terhadap variabel terikat. Pengaruh yang diberikan dari variabel bebas tersebut bersifat positif artinya semakin tinggi pelayanan maka mengakibatkan semakin tinggi pula tingkat kepuasan konsumen. Hasil tersebut sesuai dengan hipotesis yang diajukan. Hasil penelitian ini juga sesuai dengan hasil penelitian sebelumnya. Penjelasan dari masing-masing pengaruh variabel dijelaskan sebagai berikut:

\section{Pengaruh Pelayanan terhadap Kepuasan}

Konsumen

Dari tabel 4.8 Hasil pengujian hipotesis $(\mathrm{H} 2)$ telah membuktikan terdapat pengaruh antara Pelayanan terhadap Kepuasan Konsumen. Melalui hasil perhitungan yang telah dilakukan diperoleh nilai t hitung sebesar 2.498 dengan taraf signifikansi hasil sebesar
0,014 tersebut lebih kecil dari 0,05, yang berarti bahwa hipotesis dalam penelitian ini menerima Ha dan menolak Ho. Pengujian ini secara statistik membuktikan bahwa Pelayanan berpengaruh positif terhadap Kepuasan Konsumen. Artinya bahwa ada pengaruh antara variabel Pelayanan terhadap Kepuasan Konsumen PT Nutri Inti Prima Perkasa.

Berdasarkan hasil output SPSS diatas diketahui bahwa nilai $\mathrm{R}$ square sebesar 0,327 atau 32,7\%yang artinya Pelayanan dapat mempengaruhi Kepuasan Konsumen hingga sebesar $3.27 \%$, dan sisanya sebesar $67,3 \%$ dapat dipengaruhi oleh variabel lain seperti harga, emosi (kepuasan dengan menggunkan Brand tertentu), biaya dan kemudahan dan lainnya.

\section{Kesimpulan dan Saran}

\subsection{Kesimpulan:}

a. Ada pengaruh yang signifikan antara Pelayanan terhadap Kepuasan Konsumen dengan $t_{\text {hitung }}=2.498$ dan $\mathrm{t}$ tabel 1.984 dengan nilai koefisien sebesar 0.430 .

b. Berdasarkan hasil output SPSS diketahui bahwa nilai $\mathrm{R}$ square sebesar $32.7 \%$ yang artinya Pelayanan dapat mempengaruhi Kepuasan Konsumen sebesar 32.7\% dan sisanya sebesar $67.3 \%$ dapat dipengaruhi oleh variabel lain. 


\subsection{Saran}

Pelayanan kepada konsumen harus lebih ditingkatkan lagi baik dari segi ketepatan waktu maupun interaksi kepada konsumen

\section{DAFTAR PUSTAKA}

Abdi, Rianse. 2009. Metodologi Penelitian Sosial dan Ekonomi (Teori Dan Aplikasi ). Bandung: CV. ALFABETA

Tjiptono Fandy. (2001). Kualitas Jasa: Pengukuran, Keterbatasan dan Implikasi Manajerial, majalah Manajemen Usahawan Indonesia. Jakarta.

Tjiptono Fandy.(2007).Pemasaran Jasa, Bayumedia, Malang

Hardiansyah .2011. Kualitas Pelayanan Publi. Yogyakarta: Gava Media.

Husein Umar, 2000, "Metode Penelitian Untuk Skripsi dan Tesis Bisnis", Jakarta, Raja Grafindo Persada.
Husain Umar. 2005.Manajemen Riset dan Perilaku Konsumen.PT. GramediaPusat: Jakarta

Kotler, Philip. 2005. Manajemen Pemasaran. Jilid II. Edisi Kesebelas. Alih Bahasa Benyamin Molan. Jakarta. : Indeks

Kotler, Philip Dan Kevin Lane Keller. 2007. Manajemen Pemasaran. Edisi Kedua Belas. Indeks : Jakarta.

Lupiyoadi, Rambat. 2001. Pemasaran Jasa. Jakarta: Penerbit Salemba Empat.

Moenir, H.A.S. 2002.Manajemen Pelayanan Umum di Indonesia. Jakarta : Bumi Aksara.

Sugiyono.(2007).Metode Penelitian pedidikan pendekatan kuantitatif, kualitatif, dan R\&D. Bandung: ALFABETA

Sugiyono. 2010.Metode Penelitian Kuantitatif Kualitatif \& RND.Bandung : Alfabeta

Tjiptono, Fandy dan Anastasia Diana. 2003. Total Quality Manajemen. Edisi Revisi. Andy: Yogyakarta 